НАУКОВИЙ ВІСНИК

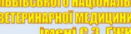

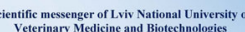

1

$\sqrt{3}$

$1=$

СЕРЯя: ВЕТЕРИНАРНН НАУКИ

Том 23 № 10

2021
Науковий вісник Дьвівського національного університету ветеринарної медицини та біотехнологій імені С.3. Гжицького. Серія: Ветеринарні науки

\author{
Scientific Messenger of Lviv National University \\ of Veterinary Medicine and Biotechnologies. \\ Series: Veterinary sciences
}

UDC 636.7/8.09:616.379-008.64:613.25

\title{
Features of correction of a pathological condition of small animals at the diabetes mellitus with obesity
}

\author{
T. P. Lokes-Krupka ${ }^{1}$, M. I. Tsvilichovsky², A. U. Karasenko ${ }^{1}$ \\ ${ }^{1}$ Poltava State Agrarian Academy, Poltava, Ukraine \\ ${ }^{2}$ National University of Life and Environmental Sciences of Ukraine, Kyiv, Ukraine
}

Article info

Received 05.01.2021

Received in revised form 08.02.2021

Accepted 09.02.2021

Poltava State Agrarian Academy Skovorody Str., 1/3, Poltava. 36003, Ukraine.

Tel.: +38-050-21-47-056

E-mail:terra_vet@ukr.net

National University of Life and Environmental Sciences of Ukraine, Heroiv Oborony Str., 15, Kyiv, 03041, Ukraine.
Lokes-Krupka, T. P., Tsvilichovsky, M. I., \& Karasenko, A. U. (2021). Features of correction of a pathological condition of small animals at the diabetes mellitus with obesity. Scientific Messenger of Lviv National University of Veterinary Medicine and Biotechnologies. Series: Veterinary sciences, 23(101), 50-54. doi: 10.32718/nvlvet10109

The article presents the results of clinical studies of domestic cats and dogs with diabetes mellitus on the background of obesity at the beginning and for a month of treatment. Domestic cats with diabetes were prescribed active exercise and industrial diet Royal Canin Diabetic Feline, dogs - Royal Canin Diabetic DS37. The portion size was determined according to the manufacturer's recommendations. Treatment of small animals for obesity, both alimentary and endocrine, preferably involves feeding food in limited quantities to cause controlled weight loss, as well as increased physical activity, which can provide additional energy expenditure. Successful weight loss can reduce the effects of comorbidities associated with obesity, such as improved mobility in osteoarthritis, increased insulin sensitivity and the reversal of other metabolic disorders, and improved quality of life. The main pathogenetic therapy for animals with diabetes for both domestic cats and dogs is the mandatory use of insulin. Researching the market of drugs in Ukraine, we chose the most affordable and effective veterinary drug-Caninsulin. The dose of insulin was selected individually for each animal by plotting a curve of blood glucose concentration over three days. At the beginning of treatment and at the end of the course, we conducted a comprehensive study of animals of both species. In cats, the general condition significantly improved as a result of treatment: only one animal remained depressed, the number of cases of hyporexia decreased, only $25.0 \%$ of animals remained pale mucous membranes; temperature within the physiological norm; vomiting and bradycardia were not reported. A decrease in the rate of shortness of breath and drowsiness also indicates an improvement in the condition of cats with obesity due to diabetes. The improvement of the general condition of domestic dogs is evidenced by the restoration of the condition of the coat (about 4 times), the restoration of appetite in $66.7 \%$. Only one dog had anemia of the mucous membranes. Anxiety, bradycardia, hypothermia and itching disappeared completely. Within one month, there was a tendency to decrease the body weight of animals of both groups, but due to the insufficient duration of treatment, their fatness still remained excessive. Which indicates the need for further correction of the pathological condition.

Key words: symptoms, hypothyroidism, endocrine obesity, overweight, dogs.

\section{Особливості корекції патологічного стану дрібних тварин за цукрового діабету на фоні ожиріння}

\author{
Т. П. Локес-Крупка ${ }^{1}$, М. І. Цвіліховський르, А. Ю. Карасенко ${ }^{1}$
}

${ }^{1}$ Полтавська державна аграрна академія, м. Полтава, Украӥна

${ }^{2}$ Національний університет біоресурсів і природокористування України, м. Київ, Украӥна

У статті наведені результати клінічних досліджень свійських котів і собак хворих на иукровий діабет на фоні ожиріння на початку та за місяць лікувальних заходів. Свійським котам за цукрового діабету призначили активний моціон і промисловий раці- 
он Royal Canin Diabetic Feline, собакам - Royal Canin Diabetic DS37. Розмір пориії визначали згідно рекомендацій виробника. Лікування дрібних тварин за ожиріння. Як аліментарного так і ендокринного переважно передбачає годівлю кормом в обмежених кількостях, щоб викликати контрольовану втрату маси тіла, а також збільшення фізичної активності, шо може забезпечити додаткові затрати енергї. Успішна втрата маси тіла може зменшити вплив супутніх захворювань, пов'язаних з ожирінням, наприклад, поліпшення рухливості за остеоартриту, підвищення чутливості до інсуліну та зворотного розвитку інших метаболічних порушень, а також поліпшення якості життя. Основною патогенетичною терапією для тварин за иукрового діабету як для свійських котів так і для собак є обов'язкове застосування препаратів інсуліну. Досліджуючи ринок препаратів в Украӥні ми обрали найбільш доступний та одночасно ефективний ветеринарний препарат - Каніснулін (Сапіпsиlin). Дозу інсуліну підбирали індивідуально для кожної тварини за допомогою побудови кривої концентрачії глюкози в крові протягом трьох діб. На початку лікування і по завершенню курсу ми проводили комплексні дослідження тварин обох видів. У котів значно покращився загальний стан внаслідок проведення лікувальних заходів: тільки одна тварина залитилась пригніченою, знизилась кількість випадків гіпорексії, тільки у 25,0 \% тварин залишалась блідість слизових оболонок; температура в межах фізіологічної норми; блювання та брадикардію не реєстрували. На покращення стану котів за ожиріння внаслідок иукрового діабету також свідчить зниження відсотку появи задишки та сонливості. На покращення загального стану свійських собак свідчить відновлення стану шерстного покриву (у близько 4-х раз), відновлення апетиту у 66,7 \%. Лише в одного собаки реєстрували анемічність слизових оболонок. Стовідсотково зник симптом занепокоєння, брадикардія, гіпотермія та свербіж. За один місяцьь відмічали тенденцію до зниження маси тіла тварин обох груп, але внаслідок недостатньої тривалості лікування їх вгодованість ще залишалась надмірною. Що свідчить на необхідість подальшої корекції патологічного стану.

Ключові слова: ендокринне ожиріння, лікування, коти, собаки

\section{Introduction}

Today veterinary practices are increasingly faced with the manifestation of endocrine pathology of different genesis. One of the leading places in the list takes diabetes. The latter is closely related to overweight and obesity of small animals.

In cats, obesity is a provoking factor in the development of diabetes is a type of insulin resistance. Disorders of carbohydrate metabolism in the body of the animal is directly related to the accumulation of fat, which leads to a number of metabolic disorders (Zimin, 2005; Zoran, 2010; Lokes-Krupka \& Tsvilikhovs'kyy, 2019).

Diabetes mellitus is a syndrome of chronic hyperglycemia caused by absolute or relative insufficiency of insulin, which causes disturbances in the metabolism of carbohydrates, lipids and proteins (McCann et al., 2007).

Obesity and diabetes are pathologies that are closely related to numerous disorders of the reproductive system, including cessation of ovulation, irregular periods, risk of abortion (Morozenko et al., 2010; Scuderi et al., 2018). Obesity and diabetes can be transmitted to offspring through gametes, which is evidence of the association of epigenetic heredity with obesity and diabetes. Some researchers claim that both obesity and diabetes can alter levels of DNA and histone methylation, histone acetylation, and noncoding RNA in oocytes and semen (Ou et al., 2018).

Treatment of cats and dogs for obesity, both alimentary and endocrine, mainly involves feeding food in limited quantities to cause controlled weight loss (Blanchard et al., 2004; Yaissle et al., 2004; German et al., 2007; German et al., 2010), as well as increased physical activity, which can provide additional energy expenditure (Vitger et al., 2016). Successful weight loss can reduce the effects of comorbidities associated with obesity, such as improved mobility in osteoarthritis (Marshall et al., 2010), increased insulin sensitivity and the reversal of other metabolic disorders (German et al., 2009; Tvarijonaviciute et al., 2012), and improved quality of life (German et al., 2012).
The obesity diet is developed by a veterinarian after examination of the animal. If you follow a natural diet, it is recommended to feed: lean meat of several varieties, lean sea fish, uncooked cereals, dairy products, vegetable oils, vitamins. All products must be easily digestible and of good quality in terms of nutritional value. Animals should be fed in small portions three times a day (German et al., 2008; Bissot et al., 2009; Owens et al., 2014; German et al., 2015; Christmann et al., 2015; Flanagan et al., 2017).

In modern veterinary practice, there are no specific protocols for the treatment of small animals with diabetes, which allows you to make a treatment plan for each animal individually.

That is why the aim of the work is to determine the directions of correction of the pathological condition of domestic cats and dogs with diabetes mellitus on the background of obesity

\section{Material and methods}

The research was conducted during 2018-2020 on the basis of veterinary clinics in Poltava and Kharkiv.

In this work we have investigated 12 domestic cat and $\operatorname{dog} 9$, in which the comprehensive survey of diagnosed diabetes symptomatic obesity. For we have taken control of clinically healthy animals with no visible signs of any pathology - 20 domestic cats and 15 domestic dogs. Registered animals admitted to veterinary clinics were examined according to the general scheme: anamnesis was collected, habit, condition of skin, visible mucous membranes were determined, thermometry, weighing, morphometric measurements and calculations were performed, functional state of organs and systems was examined (McCann et al., 2007; Lokes-Krupka, 2019).

Correction of the pathological condition of animals in both experimental groups was aimed at correcting the diet, the introduction of additional exercise and insulin therapy. Additionally, if necessary, the animals were given symptomatic treatment. Clinical evaluation of the effectiveness of treatment of animals was performed 30 days after treatment. 


\section{Results and discussion}

Domestic cats with diabetes were prescribed active exercise and industrial diet Royal Canin Diabetic Feline, dogs - Royal Canin Diabetic DS37. The portion size was determined according to the manufacturer's recommendations.

Royal Canin Diabetic Feline - an industrial diet designed specifically for cats with diabetes on the background of obesity.

Royal Canin Diabetic DS37 food is recommended for continuous use in dogs with diabetes throughout life. Because the use of this food in dogs significantly increases insulin sensitivity, it is important to monitor blood glucose levels to adjust the dose of insulin. The daily recommended feeding rate into two portions.

The main pathogenetic therapy for animals with diabetes for both domestic cats and dogs is the mandatory use of insulin. Researching the market of drugs in Ukraine, we chose the most affordable and effective veterinary drug - Caninsulin.

The dose of insulin was selected individually for each animal by plotting a curve of blood glucose concentration over three days.

The beginning of therapy was started with a dose of Caninsulin $0.25 \mathrm{IU} / \mathrm{kg}$ twice a day. After insulin, cats were given half the daily dose of food for one hour after each injection. Urine tests were performed once a week, and blood tests were performed 3 times for the first three to five days with an interval of 6-8 hours, and the insulin dose curve was established. Ideal: 9:00 - 12.0 $18.0 \mathrm{mmol} / \mathrm{l} ; 15: 00$ - 6.0-10.0 mmol/l; 21:00 - 12.0$18.0 \mathrm{mmol} / \mathrm{l}$.

It should be noted that blood glucose levels do not show the duration of hyperglycemia. Selecting a dose of insulin based on urine parameters can be dangerous. The presence of glucose in the urine indicates only that at some point the concentration of glucose in the blood was above the renal threshold (Lokes-Krupka \& Tsvilikhovs'kyy, 2019).

A possible complication of insulin therapy in the initial stages of treatment may be hypoglycemia. In such cases, there is an increase in appetite, weakness, muscle tremor, anxiety, blood glucose below $6 \mathrm{mmol} / 1$, which is critical for the animal. In this case, cats and dogs were immediately fed sugar syrup. After selecting an individual dose of the drug, the clinical picture stabilized.

At the beginning of treatment and at the end of the course, we conducted a comprehensive study of animals of both species. The results are shown in tables 1-2.

\section{Table 1}

Clinical manifestations of diabetes mellitus on the background of obesity in a cats before and after treatment

\begin{tabular}{lcccc}
\hline \multirow{2}{*}{ Clinical sign } & At the beginning of treatment, $\mathrm{n}=12$ & \multicolumn{3}{c}{30 days after treatment, $\mathrm{n}=12$} \\
\cline { 2 - 5 } & animals & $\%$ & animals & $\%$ \\
\hline Overweight, obesity & 12 & 100.0 & 10 & 83.3 \\
Rapid fatigue & 9 & 75.0 & 6 & 50.0 \\
Dyspnea & 6 & 50.0 & 4 & 33.3 \\
Drowsiness & 6 & 50.0 & 4 & 33.3 \\
Violation of the condition of the coat & 9 & 75.0 & 2 & 16.6 \\
(hair wrinkling, xerosis) & & 0.0 & 0 & 0.0 \\
Lameness & 0 & 66.7 & 4 & 33.3 \\
Hypo / anorexia & 8 & 75.0 & 2 & 16.6 \\
Polydipsia & 9 & 41.7 & 0 & 0.0 \\
Itch & 5 & 50.0 & 1 & 8.3 \\
Depressed state & 6 & 50.0 & 1 & 8,3 \\
Anxious state & 6 & 75.0 & 3 & 25.0 \\
Anemia of mucous membranes & 9 & 83.3 & 2 & 16.6 \\
Polyuria & 10 & 0.0 & 1 & 8.3 \\
Weight loss & 0 & 25.0 & 0 & 0.0 \\
Vomiting & 3 & 16.6 & 0 & 0.0 \\
Bradycardia & 2 & 25.0 & 0 & 0.0 \\
Hypothermia & 3 & 0.0 & 0 & 0.0 \\
Eye diseases (corneal dystrophy) & 0 & & & \\
\hline
\end{tabular}

In cats, the general condition significantly improved as a result of treatment: only one animal remained depressed, the number of cases of hyporexia decreased, only $25.0 \%$ of animals remained pale mucous membranes; temperature within the physiological norm; vomiting and bradycardia were not reported. However, significant weight loss was observed in only one animal, indicating the need to continue treatment. A decrease in the rate of shortness of breath and drowsiness also indicates an improvement in the condition of cats with obesity due to diabetes.
Analyzing the data in Table 2, it can be argued about improving the general state of domestic dogs. As the pathology is characterized by chronicity of the process, there is dullness and wrinkling of the fur in $88.9 \%$ of experimental dogs at the beginning of treatment and $22.2 \%$ of animals 30 days after it, which is 4 times lower than at the beginning of treatment. On the improvement of animal health as evidenced restore appetite in $66.7 \%$ of domestic dogs. Only one dog had anemia of the mucous membranes. Anxiety, bradycardia, hypothermia and itching disappeared completely. However, obesity 
decreased by only $11.1 \%$, ie in one month there was a tendency to decrease the body weight of animals, but due to the insufficient duration of treatment, their fatness still remained excessive.
Only one dog had polyuria and polydipsia after treatment. Vomiting was not recorded in dogs for 1 month of diet therapy.

\section{Table 2}

Clinical manifestations of diabetes mellitus on the background of obesity in dogs before and after treatment

\begin{tabular}{|c|c|c|c|c|}
\hline \multirow{2}{*}{ Clinical sign } & \multicolumn{2}{|c|}{ At the beginning of treatment, $n=9$} & \multicolumn{2}{|c|}{30 days after treatment, $\mathrm{n}=9$} \\
\hline & animals & $\%$ & animals & $\%$ \\
\hline Overweight, obesity & 9 & 100.0 & 8 & 88.9 \\
\hline Rapid fatigue & 4 & 44.4 & 2 & 22.2 \\
\hline Dyspnea & 4 & 44.4 & 1 & 11.1 \\
\hline Drowsiness & 3 & 33.3 & 2 & 22,2 \\
\hline $\begin{array}{l}\text { Violation of the condition of the coat } \\
\text { (hair wrinkling, xerosis) }\end{array}$ & 8 & 88.9 & 2 & 22.2 \\
\hline Lameness & 0 & 0.0 & 0 & 0.0 \\
\hline Hypo / anorexia & 8 & 88.9 & 2 & 22.2 \\
\hline Polydipsia & 6 & 66.7 & 1 & 11.0 \\
\hline Itch & 2 & 22.2 & 0 & 0.0 \\
\hline Depressed state & 5 & 55.5 & 1 & 11.1 \\
\hline Anxious state & 4 & 44.4 & 0 & 0 \\
\hline Anemia of mucous membranes & 7 & 77.8 & 1 & 11.1 \\
\hline Polyuria & 7 & 77.8 & 1 & 11.1 \\
\hline Weight loss & 0 & 0.0 & 0 & 0.0 \\
\hline Vomiting & 2 & 22.2 & 0 & 0.0 \\
\hline Bradycardia & 2 & 22.2 & 0 & 0.0 \\
\hline Hypothermia & 2 & 22.2 & 0 & 0.0 \\
\hline Eye diseases (corneal dystrophy) & 0 & 0.0 & 0 & 0.0 \\
\hline
\end{tabular}

\section{Conclusions}

Therefore, our proposed treatment scheme for a domestic cat with diabetes mellitus on the background of obesity is effective, but needs further application. Animals of both species are recommended for life to follow a diet. Continuous supervision of the animal by a veterinarian and periodic re-laboratory tests are mandatory.

Prospects for further research. In further research, we will conduct a comparative analysis of functional and structural changes in the internal organs of domestic dogs in different types of obesity, as well as determine the effectiveness of correction of the pathological condition of animals.

\section{Conflict of interest}

The authors declare that there is no conflict of interest.

\section{References}

Bissot, T., Servet, E., Vidal, S., Deboise, M., Sergeraert, R., Egron, E. et al. (2009). Novel dietary strategies can improve the outcome of weight loss programmes in obese client-owned cats. J Fel Med Surg, 12(2), 104-112. doi: 10.1016/j.jfms.2009.07.003.

Blanchard, G., Nguyen, P., Gayet, C., Leriche, I., Siliart, B., \& Paragon, B. M. (2004). Rapid weight loss with a high-protein low energy diet allows the recovery of ideal body composition and insulin sensitivity in obese dogs. J Nutr, 134(8), 2148-2150. doi: $10.1093 / \mathrm{jn} / 134.8 .2148 \mathrm{~S}$.
Christmann, U., Bečvářová, I., Were, S. R., \& Meyer, H. P. (2015). Effectiveness of a new dietetic weight management food to achieve weight loss in client-owned obese cats. J Fel Med Surg, 18, 947-953. doi: $10.1177 / 1098612 X 15599823$.

Flanagan, J., Bissot, T., Hours, M.-A., Moreno, B., Feugier, A., \& German, A. J. (2017). Success of a weight loss plan for overweight dogs: The results of an international weight loss study. PLoS ONE, 12. doi: 10.1371/journal.pone.0184199.

German, A. J., Hervera, M., Hunter, L., Holden, S. L., Morris, P. J., Biourge, V. et al. (2009). Insulin resistance and reduction in plasma inflammatory adipokines after weight loss in obese dogs. Domest Anim Endocrin, 37(4), 214-226. doi: 10.1016/j.domaniend.2009.07.001.

German, A. J., Holden, S. L., Bissot, T., Hackett, R. M., \& Biourge, V. (2007). Dietary energy restriction and successful weight loss in obese client-owned dogs. J Vet Intern Med, 21(6), 1174-1180. doi: 10.1892/06280.1

German, A. J., Holden, S. L., Bissot, T., Morris, P. J., \& Biourge, V. (2008). Changes in body composition during weight loss in obese client-owned cats: loss of lean tissue mass correlates with overall percentage of weight lost. J Fel Med Surg, 10, 452-459. doi: 10.1016/j.jfms.2008.02.004.

German, A. J., Holden, S. L., Bissot, T., Sergheraert, R., Biourge, V., \& German, A. J. (2010). A high protein high fibre diet improves weight loss in obese dogs. Vet J, 183, 294-297. doi: 10.1016/j.tvj1.2008.12.004.

German, A. J., Holden, S. L., Wiseman-Orr, M. L., Reid, J., Nolan, A. M., Biourge, V. et al. (2012). Quality of life is reduced in obese dogs but improves after suc- 
cessful weight loss. Vet J, 192(3), 428-434. doi: 10.1016/j.tvj1.2011.09.015.

German, A. J., Titcomb, J. M., Holden, S. L., Queau, Y., Morris, P. J., \& Biourge, V. (2015). Cohort study of the success of controlled weight loss programs for obese dogs. J Vet Intern Med. 29(6), 1547-1555. doi: 10.1111 jvim. 13629 .

Lokes-Krupka, T. P. (2019). Klinichnyy vypadok alimentarnoho ozhyrinnya u sobaky. Visnyk PDAA, 2, 213218. doi: 10.31210/visnyk2019.02.28 (in Ukrainian).

Lokes-Krupka, T. P., \& Tsvilikhovs'kyy, M. I. (2019). Klinichni ta morfometrychni pokaznyky u sviys'kykh kota i sobaky za nayavnosti ozhyrinnya, shcho zumovleno tsukrovym diabetom. Visnyk PDAA, 3, 221-227. doi: 10.31210/visnyk2019.03.30 (in Ukrainian).

Marshall, W. G., Hazelwinkel, H. A. W., Mullen, D. et al. (2010). The effect of weight loss on lameness in obese dogs with osteoarthritis. Vet Res Comm, 34(3), 241253. doi: $10.1007 \% 2 F s 11259-010-9348-7$.

McCann, T. M., Simpson, K. E., Shaw D. J. et al. (2007). Feline diabetes mellitus in the UK: the prevalence within an insured cat population and a questionnairebased putative risk factor analysis. J Feline Med Surg, 9(4), 289-299. doi: 10.1016/j.jfms.2007.02.001.

Morozenko, D. V., Timoshenko, O. P., \& Vodop'yanova, L. A. (2010). Gistologicheskaya kartina podzheludochnoyzhelezy i biokhimicheskiye kriterii diagnostiki pri sakharnomdiabete $\mathrm{u}$ domashnikh koshek. Vísnyk PDAA, 3, 122-124. URL: https://www.pdaa.edu.ua/sites/default/files/visnyk/201 0/03/122 124.pdf (in Russian).

Ou, X. H., Zhu, C. C., \& Sun, S. C. (2018). Effects of obesity and diabetes on the epigenetic modification of mammalian gametes. J Cell Physiol, 234(6), 78477855. doi: $10.1002 /$ jcp. 27847.

Owens, T. J., Larsen, J. A., Farcas, A. K., Nelson, R. W., Kass, P. H., \& Fascetti, A. J. (2014). Total dietary fiber composition of diets used for management of obesity and diabetes mellitus in cats. J Am Vet Med Assoc, 245(1), 99-105. doi: 10.2460/javma.245.1.99.

Scuderi, M. A., Ribeiro Petito, M., Unniappan, S., Waldner, C., Mehain, S., McMillian, C. J., \& Snead, E. C. (2018). Safety and efficacy assessment of a GLP-1 mimetic: insulin glargine combination for treatment of feline diabetes mellitus. Domest Anim Endocrinol, 65, 80-89. doi: 10.1016/j.domaniend.2018.04.003.

Tvarijonaviciute, A., Ceron, J. J., Holden, S. L., Biourge, V., Morris, P. J., \& German, A. J. (2012). Obesityrelated metabolic dysfunction in dogs: a comparison with human metabolic syndrome. BMC Vet Res, 8, 147 doi: 10.1186/1746-6148-8-147.

Vitger, A. D., Stallknecht, B. M., Nielsen, D. H., \& Bjornvad, C. R. (2016). Integration of a physical training program in a weight loss plan for overweight pet dogs. J Am Vet Med Assoc, 248(2), 174-182. doi: 10.2460/javma.248.2.174.

Yaissle, J. E., Holloway, C., \& Buffington, C. A. (2004). Evaluation of owner education as a component of obesity treatment programs for dogs. J Am Vet Med Assoc, 224(12), 1932-1935. doi: 10.2460/javma.2004.224.1932.

Zimin, N. L. (2005). Endokrinologiya v prakticheskoy veterinarii. Veterinarnyy konsul'tant, 17, 10-15 (in Russian).

Zoran, D. L. (2010). Obesity in dogs and cats: a metabolic and endocrine disorder. Vet Clin North Am Small Anim Pract, 40(2), 221-239. doi: 10.1016/j.cvsm.2009.10.009. 